\title{
Veined Rapa Whelk (Rapana Venosa) Range Extensions in the Virginia Waters Of Chesapeake Bay, USA
}

JM Harding

Virginia Institute of Marine Science

Roger L. Mann

Virginia Institute of Marine Science

Follow this and additional works at: https://scholarworks.wm.edu/vimsarticles

Part of the Marine Biology Commons

\section{Recommended Citation}

Harding, JM and Mann, Roger L., "Veined Rapa Whelk (Rapana Venosa) Range Extensions in the Virginia Waters Of Chesapeake Bay, USA" (2005). VIMS Articles. 454.

https://scholarworks.wm.edu/vimsarticles/454 


\title{
VEINED RAPA WHELK (RAPANA VENOSA) RANGE EXTENSIONS IN THE VIRGINIA WATERS OF CHESAPEAKE BAY, USA
}

\author{
JULIANA M. HARDING* AND ROGER MANN \\ Department of Fisheries Science, Virginia Institute of Marine Science, College of William and Mary, \\ P.O. Box 1346, Gloucester Point, Virginia 23062
}

\begin{abstract}
Three recent range extensions for the Chesapeake Bay, Virginia, veined rapa whelk (Rapana venosa) population are described. These extensions into Tangier Sound, the mid James River estuary, and to Cape Henry at the Bay mouth extend respectively, the northern, western, and southeastern boundaries of the occupied rapa whelk range in Virginia waters. Salinity and tidal circulation mediate the distribution of adults and larvae of this animal. During dry years (e.g., 2001 and 2002) adult rapa whelks may move up-estuary in western tributaries like the James River, given increased salinity and available habitat and food resources. Declines in salinities (or return to normal salinities) will either kill the rapa whelks in the upriver habitats or force a return to downstream habitats.
\end{abstract}

KEY WORDS: veined rapa whelk, Rapana venosa, range extension, Chesapeake Bay, salinity tolerance, Tangier Sound, James River, Cape Henry, biological invasion

\section{INTRODUCTION}

Veined rapa whelks (Rapana venosa) are large predatory marine gastropods that, to date, are the progenitors of four known successful invasions into estuarine habitats around the world. Although native to Asian waters around Japan and Korea (Tsi et al. 1983), rapa whelks were discovered in Novorossiysky Bay in the Black Sea in the mid 1940s (Drapkin 1963) and in the ensuing 60 y have spread throughout the Aegean, Adriatic and Mediterranean Seas (Drapkin 1963, Chukhchin 1984, Zolotarev 1996, Mann et al. 2004) and entered the Chesapeake Bay, Virginia, (Harding \& Mann 1999). Isolated adults and egg masses have been reported from the Brittany coast of France (1999, Dr. Philippe Goulletquer, IFREMER, personal communication) and the Rio del Plata, Uruguay and Argentina (Pastorino et al. 2000, F. Scarabino, National Museum of Natural History and National Institute of Fisheries, Uruguay, pers. comm.). Ballast water transport of the planktonic larval stage between habitats is the most likely vector of introduction across traditional zoogeographic boundaries.

Once a founder population is established within a basin or water body, expansion of the range within the basin or propagation of the invasion front may be the result of larval dispersal from nursery areas via tidal currents, migration of juvenile and adult whelks, or human mediated transport via ballast water, dredge spoils or seed oysters. Continued propagation of the invasion front from initial founder populations is dependent on sufficient propagule pressure, the rate at which breeding individuals are released by adults (Williamson 1996), to establish and sustain new self-sufficient populations at a distance from the original. Numerous models have been proposed to describe invasion front dynamics (e.g., exponential growth, Skellam 1951, Williamson 1989; traveling wave, Skellam 1951; irregular spread with occasional leaps, e.g., Mollinson 1977, Baker 1986, and these include initial population density, demographics and propagule pressure as factors mediating the rate of invasion front expansion in the new habitat, Williamson 1989).

The first collections of rapa whelk adults and egg masses in the Chesapeake Bay were made in the lower James River, Virginia (Fig. 1) during summer 1998 (Harding \& Mann 1999). Shortly

\footnotetext{
*Corresponding author. E-mail: jharding@ vims.edu
}

after the first collection of rapa whelks from Hampton Roads, the Virginia Institute of Marine Science (VIMS) established a rapa whelk bounty program to facilitate collection of the animals, and documentation of their distribution and demographics within the Chesapeake Bay. Between September 1998 and July 1999, donations of rapa whelks by commercial watermen and local citizens had established range boundaries within the Chesapeake Bay. The northern boundary was the mouth of the Rappahannock River and was established by the collection of a single specimen at Butler's Hole oyster reef by these authors in November 1998. The southeastern boundary has been the mouth of Lynnhaven Inlet near the Chesapeake Bay Bridge Tunnel in the vicinity of Ocean View and Little Creek (Fig. 1) with the western boundary as the State Route 258 Bridge across the James River. The bulk of the 10,232 rapa whelks donated to the VIMS bounty program from 1998 through February 15, 2005 have been within these boundaries. We report here on three recent rapa whelk range extensions within the Chesapeake Bay.

\section{METHODS AND RESULTS}

All whelks described herein were donated to VIMS rapa whelk bounty program (Harding \& Mann 1999, Mann \& Harding 2000). The bounty program remains an efficient although opportunistic method to sample local habitats for rapa whelks and document the distribution and demographics of this animal in collaboration with local watermen. The bulk of donations come from commercial hard clam (Mercenaria mercenaria) and blue crab (Callinectes sapidus) fishermen with additional donations from oyster (Crassostrea virginica), channelled whelk (Busycotypus canaliculatus) and knobbed whelk (Busycon carica) fishermen. To date, over 160 local fishermen contribute to the bounty program and with an estimated annual total number of sampling events in the thousands.

\section{Range Extension 1}

From June through August 2003, 14 rapa whelks ranging from 124- to $150-\mathrm{mm}$ shell length (SL: the maximum dimension from the tip of the spire to the end of the columella, $\mathrm{mm}$ ) were collected north and east of Cape Henry (Fig. 1) extending the eastern range boundary from the mouth of Lynnhaven Inlet to the mouth of the Chesapeake Bay. An additional collection of an adult rapa whelk 


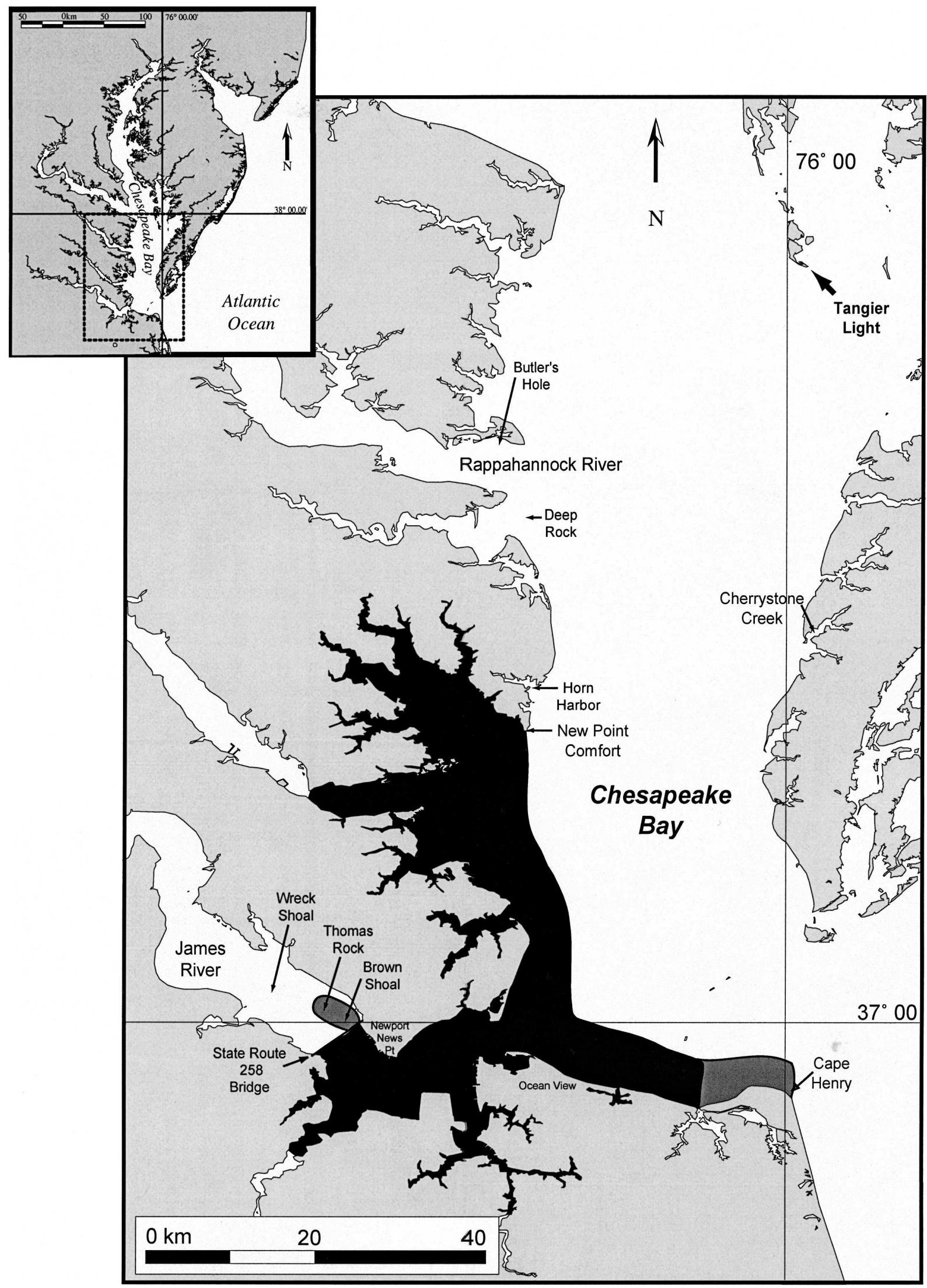

Figure 1. Map of the Virginia portion of the Chesapeake Bay showing the area occupied by the majority of the Chesapeake Bay rapa whelk population from 1998 through February 15, 2005 (black area) with subsequent range extensions (dark grey areas) into the midJames River and to Cape Henry at the mouth of the Chesapeake Bay. The single collection at Tangier Light in Tangier Sound is indicated with a large black arrow. 
(147-mm SL) from the mouth of the Bay at Cape Henry in January 2005 indicates that this range expansion may be permanent.

\section{Range Extension 2}

The lower James River, Virginia (Fig. 1) supports most of Virginia's extant commercial oyster fishery and has been the focus of monitoring and management activity for decades (e.g., Andrews 1951, Haven et al. 1981, Haven \& Fritz 1985, Mann 1988, Mann \& Evans 1998, 2004). This area is fished seasonally with the bulk of activity occurring from October through March pending management by the Virginia Marine Resources Commission. Prior to December 2004, less than five adult rapa whelks had been donated from collections made above the State Route 258 James River Bridge (Fig. 1). Between December 1, 2004 and March 1, 2005 we have received seven live rapa whelks (89-114 $\mathrm{mm} \mathrm{SL}$ ) and 37 empty rapa whelk shells (115-146 mm SL) from the vicinity of Brown Shoal and Thomas's Rock (Fig. 1). These oyster rocks are below Deep Creek and Wreck Shoal on the north side of the James River channel thus setting a new upriver (western) range boundary for rapa whelks in the James River in between Brown Shoal and Wreck Shoal.

More than $50 \%$ of the empty rapa whelk shells from these James River oyster rocks have at least one settled oyster on the shell surface ranging in size from $5 \mathrm{~mm}$ (spat settled in 2004) to $>76 \mathrm{~mm}$ (probably animals that settled in 2003 or earlier). We do not typically see oysters growing on live rapa whelks that are turned in through the bounty program. Live whelks burrow into sand or mud substrates (Bombace et al. 1994, Harding \& Mann 1999) avoiding settlement by oysters and other epifaunal biota.

\section{Range Extension 3}

In February 2005, a single adult rapa whelk (146-mm SL) was donated to VIMS from an oyster fisherman working oyster grounds near Tangier Light (Fig. 1). The animal was collected in approximately $10 \mathrm{~m}$ of water on oyster bottom. Apparently, this particular reef had not been opened for fishing activity in several years. Ancedotally, two or three additional rapa whelks of approximately the same size were collected from the same site at the same time but were not donated to VIMS so these collections cannot be positively confirmed as additional rapa whelks. This confirmed collection extends the northern rapa whelk range boundary from the mouth of the Rappahannock River to just below Tangier Island in the mainstem of the Chesapeake Bay.

\section{DISCUSSION}

The three reported range extensions for rapa whelks effectively fill in/out the spatial coverage of the habitat known to be occupied by this animal in the Virginia portion of the Chesapeake Bay (Fig. 1). Because the invasion front has expanded, the propagule pressure behind it is as yet unknown and we do not know where the Chesapeake Bay rapa whelk population lies with regard to the potential for exponential growth phase of population expansion (Williamson 1996).

The southeastern range extension out to Cape Henry and the Bay mouth is probably a natural expansion of the large rapa whelk population off Ocean View ( $n$ of 3,506 whelks donated to VIMS from Ocean View between September 1, 1998 and February 15, 2005). This extension is probably representative of seasonal migration or foraging activity by adult whelks although tidal currents in the region would facilitate larval transport from Ocean View toward Cape Henry on the outgoing tide (Fig. 1).

The western range extension up the James River from the SR 258 Bridge upriver into previously unoccupied oyster habitats just south of Wreck Shoal, including Thomas's Rock and Brown Shoal, is alarming. The collection sites for these James River rapa whelks are near the traditional oyster seed area where salinity is typically $>10$ ppt for most of the year (Haven \& Fritz 1985, Southworth \& Mann 2004, Southworth et al. In prep.). The distribution of rapa whelk adults and larvae in Chesapeake Bay is probably limited most by environmental tolerances although suitable habitat and food availability certainly will effect colonization success. Whereas the salinity tolerances of adult rapa whelks in Chesapeake Bay have not explicitly been tested, adult rapa whelks held in flow through conditions at VIMS on the York River, Virginia (Fig. 1) have survived exposure to salinities as low as $10 \mathrm{ppt}$ for several days (J. M. Harding, unpublished data). Assuming a 10 ppt survival threshold for rapa whelks, these animals might be found as far upriver in the James River as Wreck Shoal (Fig. 1) during very dry years when the normal salinity range at Wreck Shoal (12-16 ppt) increases to $>20 \mathrm{ppt}$ (Southworth et al. 2003). It is likely that most of the rapa whelks found in the Thomas Rock and Brown Shoal region migrated upriver during 2001 or 2002, which were very dry years (Southworth et al. 2002, 2003, Southworth \& Mann 2004), and were subsequently killed during the very wet years of 2003 and 2004 (Southworth et al. 2004, 2005, In prep.). During June 2003, salinities at Wreck Shoal were below $10 \mathrm{ppt}$ for several consecutive weeks (Southworth et al. 2004). Empty rapa whelk shells subsequently provided settlement substrate for oysters (see above).

If rapa whelks were present on these oyster rocks in the James River between May and August and laid egg cases, which subsequently hatched, larval transport upriver from the collection sites would be facilitated by the prevailing tidal circulation and sequence of gyres (Wood \& Hargis 1971, Mann 1988, Ruzecki \& Hargis 1989). Rapa whelk veligers will survive exposure to salinities down to $7 \mathrm{ppt}$ for $48 \mathrm{~h}$ at $24^{\circ} \mathrm{C}$ to $26^{\circ} \mathrm{C}$ (Mann \& Harding 2003). Mann (1988) described oyster veliger distribution and transport in the lower James River and estimated that oyster veligers could be transported from Newport News Point to Wreck Shoal (Fig. 1) in saline bottom water within a few days. Similar transport of rapa whelk veligers within the lower James River estuary is possible, although the absence of small rapa whelks from these collections and the more than 750 patent tong grabs made annually since 1993 on the oyster reefs upriver of Deep Creek as part of a fishery independent stock assessment, conducted jointly by VIMS and the Virginia Marine Resources Commission Conservation and Replenishment Division (VMRC, see Mann et al. 2004, Southworth et al. In prep.), indicates that recruitment to these habitats by rapa whelks is at best limited and related to prevailing salinity conditions.

The rapa whelk collection from Tangier Sound is cause for concern because of the size of the individual and the magnitude of the range expansion to the north. We have suspected that the circulation in the Chesapeake Bay, which moves in a northerly direction along Virginia's Eastern Shore (Pritchard 1952, Fig. 1), might be a vector to transport veligers hatched off Ocean View and entrained in the tidal circulation to Tangier and Pocomoke Sounds, as well as the western tributaries (i.e., Rappahannock River). In the absence of additional collections and multiple size classes of animals, it is impossible to know if this whelk from Tangier Sound 
was resident until its collection, migrated from a southern population or was transported to Tangier Sound with oyster seed from Deep Rock oyster reef at the mouth of the Piankatank River during repletion activities conducted by VMRC in 2001 (Wesson 2001). In any case, the presence of such a large whelk combined with the reports of concurrently collected (and released) whelks in a region that has productive oyster reefs and active oyster restoration sanctuary sites is not good news. The number of rapa whelk collections recorded to date north of New Point Comfort (Fig. 1) on the western shore is limited: Rappahannock River mouth (1 rapa whelk, November 1999, 130 mm SL), Deep Rock at the Piankatank River mouth (2 rapa whelks, February 2000, 125 and $130 \mathrm{~mm}$ SL), and Horn Harbor (2 rapa whelks, June 2001, 150 and $167 \mathrm{~mm}$ $\mathrm{SL})$. The number of rapa whelks reported from the Bay side of Virginia's Eastern Shore is less than 10 with the northernmost of these collections in Cherrystone Creek (Fig. 1; 4 rapa whelks, June (95 mm SL) and August 2000 (105 mm SL), June (118 mm SL) and November 2003 (104 mm SL).

While this Tangier Sound collection does represent a northern range extension for rapa whelks in the Chesapeake Bay, this collection is still but one record that shows the expansion of the invasion front and represents less than $1 \%$ of all animals collected to date. At this time, $99 \%$ of the veined rapa whelks collected in the Chesapeake Bay have been collected from locations south of New Point Comfort (Fig. 1). Note that areas throughout the Virginia portion of Chesapeake Bay receive annual coverage by fishermen participating in the commercial clam, oyster, crab and local whelk fisheries. The Tangier rapa whelk collection is a cause for concern, continued monitoring and removal of whelks if possible but not panic.

\section{ACKNOWLEDGMENTS}

The authors thank A. Bohannon, K. Capposela, L. Carpenter, C. Conrath, E. Darrow, T. Drummond, M. Fagan, C. Forrester, C. Harris, S. Haywood, R. Howlett, E. Jestel, M. Kellum, D. Kerstetter, P. Kingsley-Smith, L. Lawson, A. Picarello, G. Reardon, M. Seebo, M. Southworth, C. Tomlinson, D. Ward, E. Westcott, and C. Ware for their assistance collecting whelks from fishermen. This research was supported by the National Fish and Wildlife Foundation (V703750) and the Department of Fisheries Science at VIMS. M. Southworth provided valuable comments on earlier drafts of this manuscript. The continuing contributions of rapa whelks to our research program by local fishermen are gratefully acknowledged. This is contribution number 2673 from the Virginia Institute of Marine Science, Gloucester Point, Virginia.

\section{LITERATURE CITED}

Andrews, J. 1951. Seasonal patterns of oyster setting in the James River and Chesapeake Bay. Ecology. 32(4):752-758.

Baker, H. 1986. Patterns of plant invasions in North America. In: H. Mooney \& J. Drake, editors. Ecology of biological invasions of North America and Hawaii. Ecological Studies 58. New York, NY: SpringerVerlag, pp. 44-57.

Bombace, G., G. Fabi, L. Fiorentini \& S. Speranaza. 1994. Analysis of the efficacy of artificial reefs located in five different areas of the Adriatic Sea. Bulletin of Marine Science 55(2-3):559-580.

Chukhchin, V. 1984. Ecology of gastropoda from the Black Sea. Naukova Dumka. Kiev. 176 pp. (In Russian).

Drapkin, E. 1963. Effect of Rapana bezoar Linne (Mollusca, Muricidae) on the Black Sea fauna. Dokl. Akad. Nauk. SSSR. 151:700-703.

Harding, J. M. \& R. Mann. 1999. Observations on the biology of the Veined Rapa whelk, Rapana venosa (Valenciennes, 1846) in the Chesapeake Bay. J. Shellfish Res. 18(1):9-18.

Haven, D., W. Hargis, Jr. \& P. Kendall. 1981. The oyster industry of Virginia: its status, problems, and promise. A comprehensive study of the oyster industry in Virginia, 2nd ed. Spec. Pap. Mar. Sci. Va. Inst. Mar. Sci. No. 4. pp. 1-1024.

Haven, D. \& L. Fritz. 1985. Setting of the American oyster Crassostrea virginica in the James River, Virginia, USA: temporal and spatial distribution. Marine Biol. 86:271-282.

Mann, R. 1988. Distribution of bivalve larvae at a frontal system in the James River, Virginia. Marine Ecology Progress Series 50:29-44.

Mann, R. \& D. Evans. 1998. Estimation of oyster, Crassostrea virginica, standing stock, larval production, and advective loss in relation to observed recruitment in the James River, Virginia. J. Shellfish Res. 17(1):239-254.

Mann, R. \& D. Evans. 2004. Site selection for oyster habitat rehabilitation in the Virginia portion of the Chesapeake Bay: A commentary. $J$. Shellfish Res. 23(1):41-49.

Mann, R. \& J. M. Harding. 2000. Invasion of a Mid Atlantic estuary by the oriental gastropod Rapana venosa Valenciennes, 1846. Biological Invasions 2:7-22.

Mann, R. \& J. M. Harding. 2003. Salinity tolerance of larval Rapana venosa: Implications for dispersal and establishment of an invading predatory gastropod on the North American Atlantic coast. Biol. Bull. 204:96-103.

Mann, R., A. Occhipinti \& J. M. Harding. 2004. Current status of global invasions by the marine gastropod Rapana venosa. First special report of the International Council for Exploration of the Seas on the status of introduced species. International Council for Exploration of the Seas/ ICES. 24th Annual meeting of ICES (WGITMO), Goteborg, Sweden, March 20-21, 2002.

Mann, R., M. Southworth, J. M. Harding \& J. A. Wesson. 2004. A comparison of dredge and patent tongs for estimation of oyster populations. J. Shellfish Res. 23(2):387-390.

Mollinson, D. 1977. Spatial contact models for ecological and epidemic spread. J. R. Statist. Soc. B. 39:283-326.

Pastorino, G., P. Penchaszadeh, L. Schejter \& C. Bremec. 2000. Rapana venosa (Valenciennes, 1846) (Mollusca: Muricidae): a new gastropod in south Atlantic waters. J. Shellfish Res. 19(2):897-899.

Pritchard, D. 1952. Salinity distribution and circulation in the Chesapeake Bay estuarine system. J Mar. Res. 11(2):106-123.

Ruzecki, E. \& W. Hargis, Jr. 1989. Interaction between circulation of the estuary of the James River and transport of oyster larvae. In: B. Neilson, J. Brubaker \& A. Kuo, editors. Estuarine circulation. Clifton, NJ: The Humana Press Inc. pp. 255-278.

Southworth, M. \& R. Mann. 2004. Decadal scale changes in seasonal patterns of oyster recruitment in the Virginia subestuaries of the Chesapeake Bay. J. Shellfish Res. 23(2):391-402.

Southworth, M., J. M. Harding \& R. Mann. 2002. The status of Virginia's public oyster resource, 2001. Molluscan ecology program, Virginia Institute of Marine Science, Gloucester Point, Virginia. 53 pp.

Southworth, M., J. M. Harding \& R. Mann. 2003. The status of Virginia's public oyster resource, 2002. Molluscan ecology program, Virginia Institute of Marine Science, Gloucester Point, Virginia. 51 pp.

Southworth, M., J. M. Harding \& R. Mann. 2004. The status of Virginia's public oyster resource, 2003. Molluscan ecology program, Virginia Institute of Marine Science, Gloucester Point, Virginia. 55 pp.

Southworth, M., J. M. Harding \& R. Mann. 2005. The status of Virginia's public oyster resource, 2004. Molluscan ecology program, Virginia Institute of Marine Science, Gloucester Point, Virginia. 50 pp.

Southworth, M., J. M. Harding \& R. Mann. 2005. In preparation. Decadal 
trends in oyster Crassostrea virginica density and biomass in three Virginia estuaries. In preparation.

Skellam, J. 1951. Random dispersal in theoretical populations. Biometrika. 38:196-218.

Tsi, C., T. Ma, Z. Lou \& F. Zang. 1983. Illustrations of the fauna of China (Mollusca), vol. 2 plates I-IV. Beijing: Science Press. 150 pp.

Wesson, J. 2001. 2001 oyster replenishment program completion report. Virginia Marine Resources Commission Conservation and Replenishment Department. Newport News, Virginia.

Williamson, M. 1989. Mathematical models of invasion. In: J. Drake, H.
Mooney, F. di Castri, R. Groves, F. Kruger, M. Rejmanek \& M. Williamson, editors. Biological invasions: a global perspective. SCOPE 37. Chichester, UK: John Wiley \& Sons. pp. 329-350.

Williamson, M. 1996. Biological invasions. New York, NY: Chapman and Hall. 244 pp.

Wood, L. \& W. Hargis. 1971. Transport of bivalve larvae in a tidal estuary., In: D. Crisp, editor. Fourth European Marine Biology Symposium. UK: Cambridge University Press. pp. 29-44

Zolotarev, V. 1996. The Black Sea ecosystem changes related to the introduction of new mollusc species. Marine Ecology. 17(1-3):227-236. 